\title{
ASSESSMENT OF EUSTACHIAN TUBE FUNCTION IN CHRONIC SUPPURATIVE OTITIS MEDIA, TUBOTYMPANIC TYPE
}

\author{
Sunitha M11, L. Asokan², A. P. Sambandan ${ }^{3}$
}

${ }^{1}$ Associate Professor, Department of ENT, Sri Muthukumaran Medical College Hospital and Research Institute, Chennai, T. N, India. ${ }^{2}$ Senior Resident, Department of ENT, Sri Muthukumaran Medical College Hospital and Research Institute, Chennai, T. N, India. 3 Professor and HOD, Department of ENT, Sri Muthukumaran Medical College Hospital and Research Institute, Chennai, T. N, India. ABSTRACT

\section{BACKGROUND}

Eustachian tube function is necessary for the graft uptake in patients with chronic suppurative otitis media, tubotympanic type. The objective of this study was to assess surgical outcome in CSOM patients, tubotympanic type based on the Eustachian tube function.

\section{MATERIALS AND METHODS}

A descriptive study was done on 100 patients with chronic suppurative otitis media, tubotympanic type. Eustachian tube function (ETF) in patients with perforated drum is assessed by impedance audiometer- Toynbee test. Patients with normal ETF were taken up for tympanoplasty. Patients with partial ETF, inactive type were taken up for tympanoplasty and active type were taken up for cortical mastoidectomy with tympanoplasty. Patients with totally impaired ETF were taken up for cortical mastoidectomy with tympanoplasty.

\section{RESULTS}

The graft uptake was analysed with respect to ETF status.

\section{CONCLUSION}

Eustachian tube function is essential for the graft uptake in chronic suppurative otitis media, tubotympanic type. In patients with inactive CSOM, normal and partially impaired ETF require tympanoplasty. In patients with partially impaired ETF, active CSOM and grossly impaired ETF, active or inactive CSOM require cortical mastoidectomy, which increases middle ear space and widens aditus. Mastoid air cells act as surgitank of air.

\section{KEY WORDS}

Chronic Suppurative Otitis Media, Tubotympanic Type, Eustachian Tube Function (ETF).

HOW TO CITE THIS ARTICLE: Sunitha M, Asokan L, Sambandan AP. Assessment of Eustachian tube function in chronic suppurative otitis media, tubotympanic type. J. Evolution Med. Dent. Sci. 2018;7(24):2901-2903, DOI: 10.14260/jemds/2018/653

\section{BACKGROUND}

Eustachian tube functions are pressure equalisation, mucociliary clearance of the middle ear cleft and protection of the middle ear from secretions and sounds from the nasopharynx. ${ }^{1}$ Eustachian tube function (ETF) is necessary for the graft uptake in chronic suppurative otitis media, tubotympanic type. The most reliable method of examining the ETF is impedance-audiometer Toynbee method. The present study was done in patients with chronic suppurative otitis media, tubotympanic type- active and inactive. Tympanoplasty with or without cortical mastoidectomy was done based on the ETF.

\section{MATERIALS AND METHODS}

A descriptive study was done on 100 patients with chronic suppurative otitis media, tubotympanic type presenting in Department of ENT at a tertiary care centre from July 2015 to June 2016. Examination was done after eliciting history.

'Financial or Other Competing Interest': None.

Submission 27-04-2018, Peer Review 27-05-2018,

Acceptance 02-06-2018, Published 11-06-2018.

Corresponding Author:

Dr. Sunitha $M$,

Associate Professor, Department of ENT,

Sri Muthukumaran Medical College Hospital and

Research Institute, Chennai, Tamilnadu, India.

E-mail: drsunithavasu@gmail.com

DOI: $10.14260 /$ jemds $/ 2018 / 653$
Examination included diagnostic nasal endoscopy, otoendoscopy, tuning fork test and pure tone audiometry. ETF was assessed by Toynbee method. X-ray mastoids were done in all the cases and HRCT temporal bone wherever required. Toynbee method for ETF was done using impedance audiometer model Madsen Zodiac 901 (Otometrics). The impedance audiometer is programmed to increase or decrease the air pressure at the middle ear. The changes in air pressure at the middle ear upon each swallowing are recorded. Air pressure at the middle ear is changed to $+200 \mathrm{daPa}$ or $-200 \mathrm{daPa}$. The ability of the patient to neutralise the positive and negative pressures upon each swallowing is recorded graphically by the impedance audiometer. Normal eustachian tube function is considered if the patients neutralise positive or negative pressure to $0 \mathrm{daPa}$ within 5 swallows and the plotted graph is a step ladder pattern. If some amount of residual pressure persists even after 5 swallows, tubal function is considered as partially impaired. If the patient is not able to neutralise the positive or negative pressure on repeated swallows, then tubal function is grossly impaired.

Treatment was done according to the findings. Patients with inactive type of CSOM, normal and partially impaired ETF were taken up for tympanoplasty. Patients with active type, partially impaired ETF and active or inactive type, grossly impaired ETF were taken up for cortical mastoidectomy with tympanoplasty. Post-operative follow- 
up was done regularly weekly till 3rd week and then every 15 days till 3rd month. Graft uptake was noted.

Statistical analysis was done by chi-square test using SPSS software for windows version 17.

\section{RESULTS}

The study was conducted on 100 patients with CSOM, tubotympanic type. There were 47 male and 53 female patients. ETF was assessed, and patients underwent tympanoplasty with or without cortical mastoidectomy accordingly. Graft uptake was assessed.

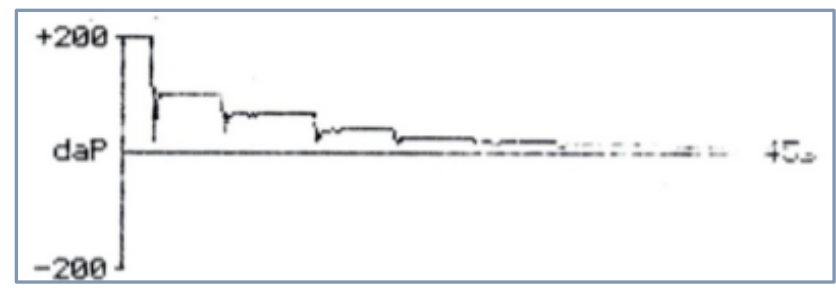

Figure 1. Normal Eustachian Tube Function

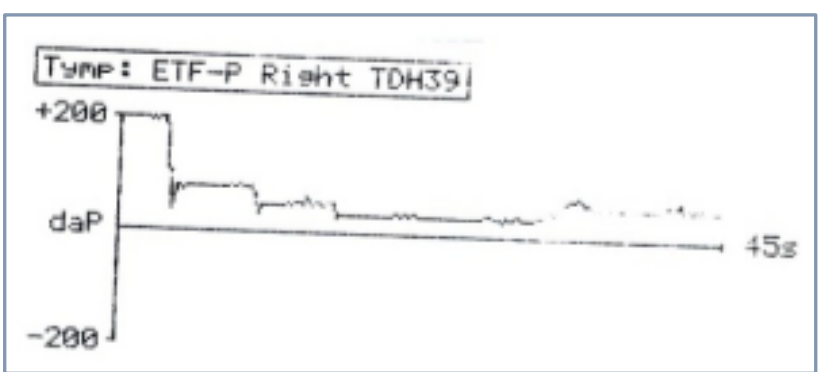

Figure 2. Partially Impaired Eustachian Tube Function

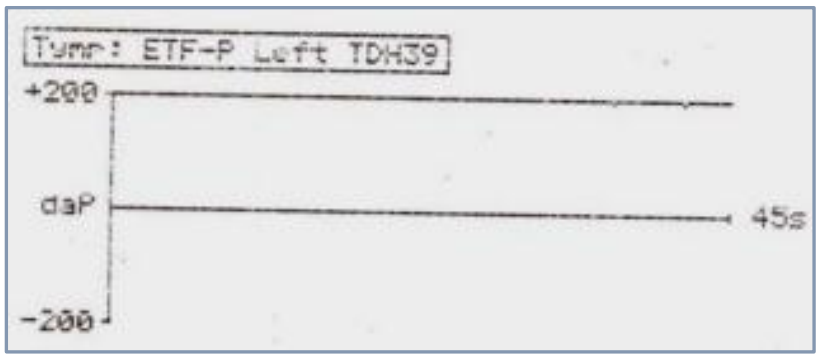

Figure 3. Totally Impaired Eustachian Tube Function

Eustachian tube function was normal in $30 \%$, partially impaired in $43 \%$ and totally impaired in $27 \%$ of the patients. Tympanoplasty was done in patients with inactive type of CSOM, normal and partially impaired ETF. Cortical mastoidectomy with tympanoplasty was done in patients with active type, partially impaired ETF and active or inactive type, grossly impaired ETF. Graft uptake was $100 \%$ in patients with normal ETF, $97.7 \%$ in patients with partially impaired ETF and $85.2 \%$ in patients with grossly impaired ETF. Statistical analysis was done, and pvalue was 0.021 .

\begin{tabular}{|c|c|c|c|}
\hline \multirow{2}{*}{\multicolumn{2}{|c|}{ Eustachian Tube Function }} & \multicolumn{2}{|c|}{ Graft Uptake } \\
\hline & & \multirow{2}{*}{$\begin{array}{c}\text { Yes } \\
30 \\
\end{array}$} & \multirow{2}{*}{$\begin{array}{c}\text { No } \\
0\end{array}$} \\
\hline Normal Function & Cases & & \\
\hline & $\%$ & $100.0 \%$ & $0 \%$ \\
\hline \multirow{2}{*}{ Partially Impaired } & Cases & 42 & 1 \\
\hline & $\%$ & $97.7 \%$ & $2.3 \%$ \\
\hline \multirow[t]{2}{*}{ Totally Impaired } & Cases & 23 & 4 \\
\hline & $\%$ & $85.2 \%$ & $14.8 \%$ \\
\hline
\end{tabular}

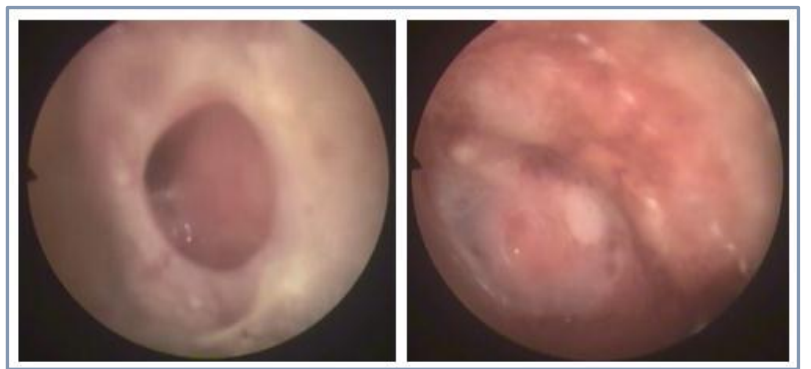

Figure 4. Endoscopic Picture of Pre-Op and Post-Op Tympanic Membrane in CSOM, TT Type, Inactive
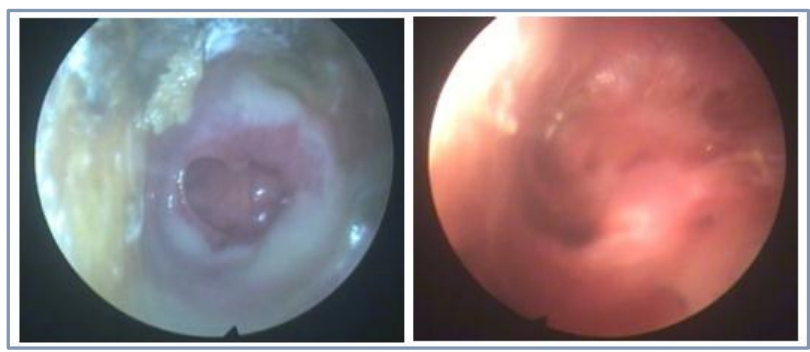

Figure 5. Endoscopic Picture of Pre-Op and Post-Op Tympanic Membrane in CSOM, TT Type, Active

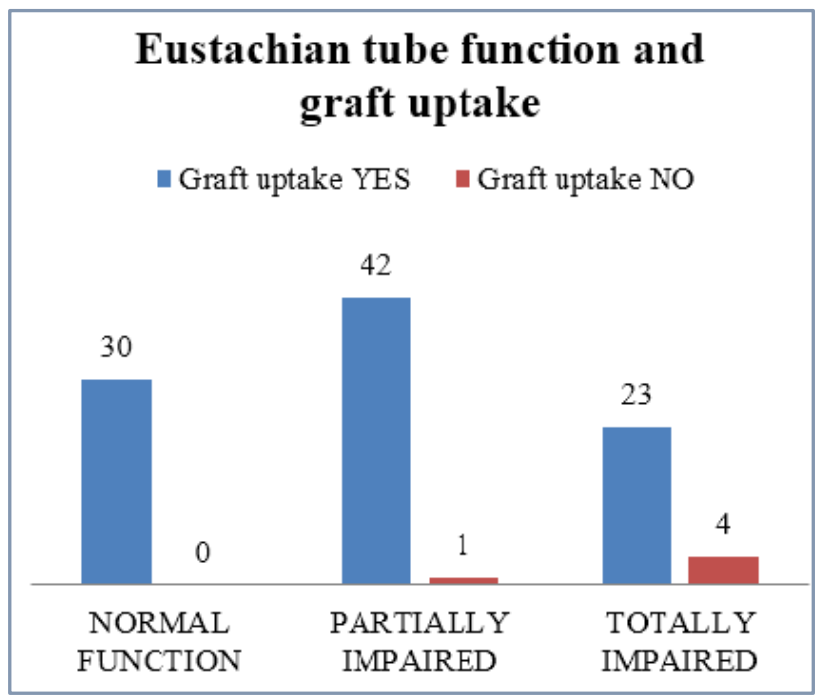

Figure 6. Eustachian Tube Function and Graft Uptake

\section{DISCUSSION}

Eustachian tube function plays a significant role in the graft uptake in patients with chronic suppurative otitis media, tubotympanic type. The importance of ETF in the outcome of middle ear surgery has been emphasised by Tos. ${ }^{2}$

Different methods of ET function in non-intact tympanic membrane are Toynbee method using impedance audiometer and forced response test. ${ }^{3}$

In a study by Cohn et al, Eustachian tube function was assessed by Toynbee method.

Graft uptake was $95 \%$ in patients with normal tubal function, $75 \%$ in partially impaired tubal function and $69 \%$ in totally impaired tubal function. ${ }^{4}$

Takahashi analysed Eustachian tube function by inflationdeflation test in 78 ears with non-cholesteatomatous chronic otitis media without ossicular damage who underwent type-I tympanoplasty and found that patients with poor pressure equalisation had poor outcomes. ${ }^{5}$ 
In a study by Priya et al the graft uptake was $100 \%$ in patients with normal tubal function, $98 \%$ in partial tubal dysfunction and $76 \%$ in total tubal dysfunction. ${ }^{6}$

In our study we had similar results with graft uptake $100 \%$ in patients with normal ETF, $97.7 \%$ in patients with partially impaired ETF and $85.2 \%$ in patients with grossly impaired ETF.

Eustachian tube is vital to the health of the tympanic membrane and middle ear as a whole. Pioneering otologists including Toynbee, Politzer and Bezold developed a paradigm that held that the Eustachian tube regulates and modulates the pneumatic status of the middle ear and mastoid to maintain the appropriate milieu for optimal sound transmission by the tympanic membrane and ossicular chain. ${ }^{7}$

In tympanoplasty, aeration of the middle ear is crucial for normal ossicular coupling. If middle ear aeration is impaired due to disease, it can adversely affect ossicular coupling by altering a pressure difference that is important to middle ear function. So tympanic membrane perforation causes hearing loss by reducing the pressure difference in sound pressure across the two sides of tympanic membranes, thereby causing reduced ossicular coupling. Post-operative aeration of the middle ear is the key to success of the tympanic membrane repair and restoration of hearing and this depends on the eustachian tube function. ${ }^{8}$

Mastoid air cells act as surgitank of air. In active chronic suppurative otitis media, simple mastoidectomy with widening of the aditus is done. Simple mastoidectomy increases the middle ear cleft space and is a good idea if there is compromised ETF. ${ }^{9}$

\section{CONCLUSION}

Eustachian tube function is essential for the graft uptake in chronic suppurative otitis media, tubotympanic type. Patients with inactive CSOM, with normal and partially impaired ETF, require tympanoplasty. Patients with partially impaired ETF, active CSOM and grossly impaired ETF, active or inactive CSOM require cortical mastoidectomy, which increases middle ear space and widens aditus. Mastoid air cells act as surgitank of air.

\section{REFERENCES}

[1] O'Reilly RC, Levi J. Anatomy and physiology of the eustachian tube. Chap - 131. In: Flint PW, Haughey BH, Lund V, et al, eds. Cummings Otolaryngology. $6^{\text {th }}$ edn. Philadelphia, PA: Elsevier Saunders 2015: p. 2031.

[2] Tos M. Importance of eustachian tube function in middle ear surgery. Ear, Nose \& Throat Journal 1998;77(9):744-7.

[3] O'Reilly RC, Levi J. Anatomy and physiology of the eustachian tube. Chap - 131. In: Flint PW, Haughey BH, Lund V, et al, eds. Cummings Otolaryngology. $6^{\text {th }}$ edn. Philadelphia, PA: Elsevier Saunders 2015: p. 2036.

[4] Cohn AM, Schwaber MK, Anthony LS, et al. Eustachain tube function and tympanoplasty. Ann Otol Rhinol Laryngol 1979;88(3 Pt 1):339-47.

[5] Takahashi H, Sato H, Nakumura H, et al. Correlation between middle-ear pressure-regulation functions and outcome of type-I tympanoplasty. Auris Nasus Larynx 2007;34(2):173-6.

[6] Priya K, Karthikeyan P, Coumare VN, et al. Evaluation of Eustachian tube function in chronic suppurative otitis media (tubotympanic type) with reference to its treatment outcome. Indian J Otol 2012;18(4):179-83.

[7] O'Reilly RC, Levi J. Anatomy and physiology of the eustachian tube. Chap - 131. In: Flint PW, Haughey BH, Lund V, et al, eds. Cummings Otolaryngology. $6^{\text {th }}$ edn. Philadelphia, PA: Elsevier Saunders 2015: p. 2027.

[8] Adams ME, El-Kashlan HK. Tympanoplasty and ossiculoplasty. Chap - 141. In: Flint PW, Haughey BH, Lund V, et al, eds. Cummings Otolaryngology. $6^{\text {th }}$ edn. Philadelphia, PA: Elsevier Saunders 2015: p. 2178.

[9] Brackmann DE, Shelton C, Arriaga MA. Otologic surgery. Chapter - 15. 4th edn. Philadelphia: Elsevier 2016: p. 164. 